\title{
Determinants of Commercialization of Tef: The Case of Smallholder Farmers in Dendi District of Oromia, Central Ethiopia
}

\author{
Addisu Getahun $^{1 *} \quad$ Degye Goshu (PHD) ${ }^{2} \quad$ Adam Bekele (PHD) ${ }^{1}$ \\ 1*.Ethiopian Institute of Agricultural Research (EIAR), Holetta Agricultural Research Center P. O. Box 2003, \\ Addis Ababa, Ethiopia \\ 1.Sinior Researcher in Ethiopian Institute of Agricultural Research (EIAR), P. O. Box 2003, Addis Ababa, \\ Ethiopia \\ 2.Associate Professor in Department of Economics, Kotebe Metropolitan Universit, P. O. Box 31248, Addis \\ Ababa, Ethiopia
}

\begin{abstract}
In Ethiopia, tef is economically and socially important cereal crop, particularly in Dendi district it is source of food and cash income for majority of the smallholder farmers. However, the supply of tef in the study area still can't satisfy the existing market demand. The study aimed at analyzing the commercialization level and factors affecting the commercialization of tef producers. The study largely uses primary data that was collected from 210 randomly selected farmers through structured and semi-structured questionnaire. Both descriptive statistics and econometric models were used. Tobit model were used to identify the determinants of commercialization. Results of the descriptive statistics indicated that $12.38 \%$ of sample households are subsistent, $3.33 \%$ are less-commercial, $43.81 \%$ are semi-commercialized and $40.48 \%$ are commercialized farmers. The average commercialization level of tef producers in the district was $46 \%$. The result of Tobit regression model revealed that educational level, livestock owned, land under tef, agricultural extension, sex of household head, household size and off/non-farm income significantly affect commercialization level of tef producers. Therefore, the findings suggest that strategies aiming at promoting tef producers' commercialization should focus on strengthening the technical, resource base and institutional capacity of smallholder farmers.
\end{abstract}

Keywords: Smallholders, Commercialization, Tobit, Tef, Dendi

DOI: $10.7176 / \mathrm{JAAS} / 56-01$

Publication date:June $30^{\text {th }} 2019$

\section{INTRODUCTION}

Agriculture continues to dominate the national economy of Ethiopia, accounting for $36.7 \%$ of overall GDP and $70 \%$ of foreign exchange earnings. The sector provides employment for $72.7 \%$ of the population and is a means of generating livelihood for about 83\% of the rural population (ATA, 2017; ADEA, 2014; FAO, 2015). In Ethiopia $95 \%$ of the total area under agriculture is cultivated by smallholder farmers and contributes to $90 \%$ of the total agricultural output indicating the dominant contribution of smallholder farmers to the overall agricultural production (MoARD, 2010; Gebreslassie and Bekele, 2012).

According to MoFED (2010, 2015), the Ethiopian government, in its two-consecutive five-years Growth and Transformation Plan (GTP-I and GTP-II), has given much emphasis on agricultural commercialization, among which the second pillar intends to achieve growth and thereby improve people's livelihoods and reduce poverty. Commercialization of the smallholder farmers has been viewed by the government as the major source of agricultural growth in Ethiopia. The government of Ethiopia implemented agricultural commercialization clusters with the primary goal of commercialization of smallholders' agriculture and agro-industrial development, offering a strategic entry point for private sector engagement (Pauw, 2017).

Commercialization entails agricultural production decision intended for market based on market signals and produce offered for sale and use of purchased inputs (Berhanu and Moti, 2010). The welfare gain of agricultural commercialization can be achieved through specialization, comparative advantage, economies of scale and flow of ideas due to regular interaction (Barrett, 2008). In the agricultural sector, cereals cover about $80 \%$ of the total grain crop area (9.97 million hectares) and contribute about $87 \%$ (23.1 million tons) of the grain production (CSA, 2016). Among cereals, tef (Eragrostis tef) stands first in terms of land area, followed by maize and wheat (CSA, 2016). Ethiopia is the center of both origin and diversity for tef(Vavilov, 1951). Tef is a staple food and one of the most important crops for generating farm income, cultural heritage, national identity and nutritional security. The study area is found in West Shewa zone of Oromia region, central Ethiopia. West Shewa zone is potential area of tef production in central Ethiopia. The land area covered by tef in the zone was 205,573.1 hectares and from it $3,808,745.7$ quintals of tef was produced during 2015/16 production year. The productivity of tef in the zone was (18.53 qt/ha) is higher than the national and regional average which was (15.6 qt/ha) (CSA, 2016). In spite of the conducive agricultural commercialization policy environment the return and incentive for growth in tef through 
agricultural commercialization faces a number demographic and marketing challenges (ATA, 2017; Pauw, 2017). There is a dearth of information in terms of identifying the determinants of smallholders' commercialization of tef producer particularly in Dendi district West Shewa zone of Oromia region, one of the potential areas of tef production in Central Ethiopia. Such information is essential for making knowledge-based decision that are geared towards improving market participation of farmers in tef and contribute to the national development goals of eradicating poverty and improving food security.

In Ethiopia, tef is an important cereal crop that covers $22.95 \%$ area of land that is under grain crops (CSA, 2016). It is first among all cultivated crops in terms area coverage and second to maize in terms of its contribution to total grain production contributing $16.76 \%$ to grain production (CSA, 2016). For this study, tef is selected, because it is primarily grown and marketed by majority of the smallholder farmers in Dendi district and it is source of food and cash income for the smallholder farmers. According to ATA (2017), Dendi district is one of the agricultural commercialization cluster areas in tef production in West Shewa zone. However, the supply of tef in the study area still can't satisfy the existing market demand and the farmers are not benefited from tef price increment.

Since tef is the most economically and socially crucial crop, there is a strong need to address the prevailing information gap and contribute to proper understanding of determinants of commercialization of smallholder farmers in Dendi district. Such information is also required to contribute to the success of GTP-II plan of the country through improved decision of smallholder farmers in tef production and marketing. Therefore, this study analyzes the level of commercialization and identify factors affecting the level of commercialization of tef producers.

\subsection{Objectives}

1. To measure the level of commercialization of tef producers in the study areas;

2. To identify the determinants of commercialization of tef producers.

\section{RESEARCH METHODOLOGY}

\subsection{The Study Area}

Dendi district is one of the thirty-three districts in West Shewa zone of Oromia region, Central Ethiopia. and lies at about $80 \mathrm{~km}$ west of Addis Abeba. The district is geographically situated within $038^{\circ} 10^{\prime} 54^{\prime \prime} \mathrm{E}$ longitude and $9^{\circ}$ $01 ' 16 " \mathrm{~N}$ latitude and at an altitude of 2200 meter above sea level. Dendi district is bordered on the south by Dawo and Wenchi, on the west by Ambo and Elfeta, on the north by Jeldu, and on the east by Ejersa Lafo districts (Figure $1)$.

According to DDAO (2017), the total population of the district is 200715 . Out of the total population $42953(21.4 \%)$ are urban dwellers and 157762(78.6\%) are rural dwellers. The total area coverage of the district is $79,936.29$ hectares of which 39,227.5 hectares are cultivated land. The district has two agro-ecologies; highland $(29 \%)$ and midland $(71 \%)$, indicating that the district is dominated by midland agro-ecology. In the district, mixed farming system of both crops and livestock is common economic activity (DDAO, 2017). Cereal crops grown in the district includes: tef, wheat, barley, maize and sorghum. Tef production takes the lion share of income generation to the farmers and the district is known for its highest production of tef.

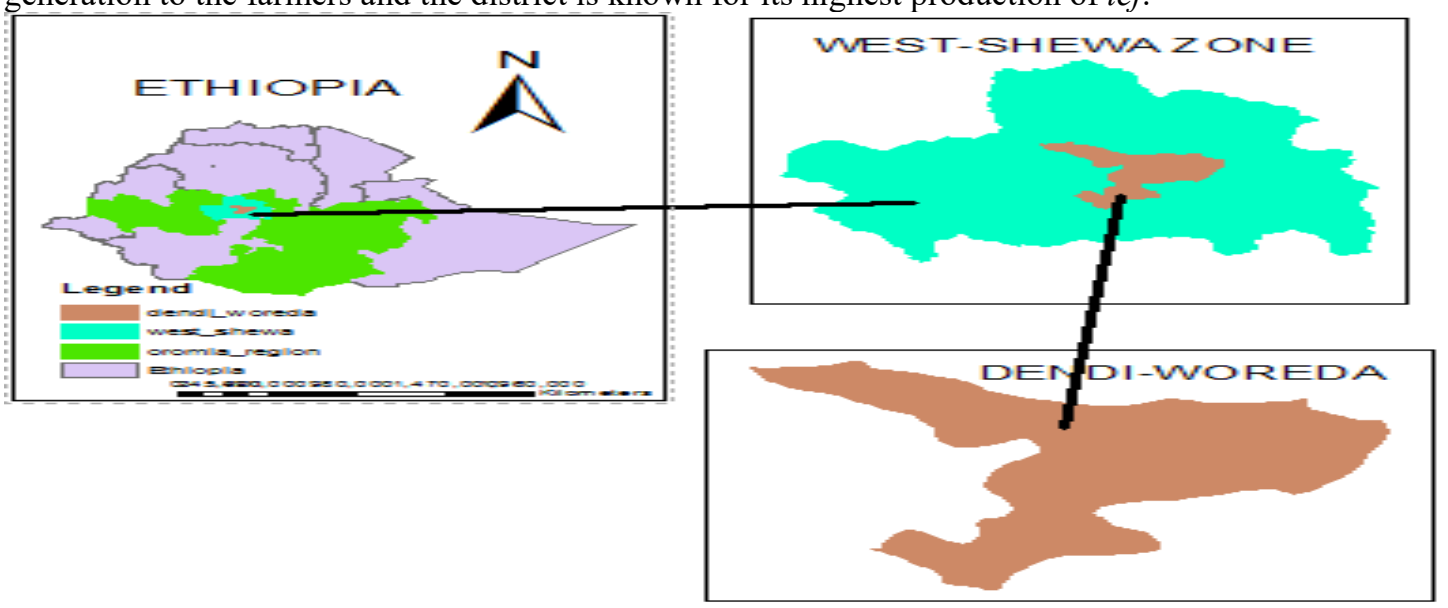

Figure 1. Location of the study area

\subsection{Data Types, Sources and Methods of Data Collection}

Both primary and secondary data were used for this study. Primary data were collected from randomly selected tef producers in five rural kebeles. Primary data were collected by structured and semi-structured questionnaires and 
by well-trained enumerators using Computer Aided Personal Interview (CAPI). Secondary data was taken by reviewing secondary sources from published and unpublished documents of Central Statistical Authority (CSA), district agricultural and rural development office. In addition, journals and websites were visited to generate relevant secondary information focusing on the objectives of the study.

\subsection{Sampling Procedure and Sample Size Determination}

The target populations for this study were smallholder tef producers in Dendi district. Purposive and two stage random sampling procedure was used for the selection of sample household heads. Dendi district was selected purposively since it is the potential area of tef production in West Shewa zone, Central Ethiopia. In the first stage, five tef producing kebeles; namely, Dano Ejersa Gibe, Wamura Sako, Lokloka Abba, Werka Werabu and Yubdo Legabatu were selected randomly from a total of 24 tef producing kebeles of the district.

In the second stage, from the total of 2425 households in the selected five kebeles, 210 sample household heads were selected randomly, using probability proportionate to size of tef producer households in the kebeles. The total sample size $(n=210)$ was determined following a simplified formula provided by Yamane (1967). Accordingly, the required sample size at $95 \%$ confidence level with degree of variability of $5 \%$ and level of precision equal to $6.6 \%$ were used to obtain a sample size required to represent the true population.

$$
n=\frac{\mathrm{N}}{1+\mathrm{N}(\mathrm{e})^{2}}
$$

Where: $\mathrm{n}=$ sample size, $\mathrm{N}=$ population size (sampling frame) and $\mathrm{e}=$ level of precision.

Table 1: Sample distribution of tef producer households in selected kebeles

\begin{tabular}{clcc}
\hline No & Kebeles & $\begin{array}{c}\text { Total number of } \\
\text { households }\end{array}$ & $\begin{array}{c}\text { Number of sampled } \\
\text { households }\end{array}$ \\
\hline 1 & Dano Ejersa Gibe & 618 & 54 \\
2 & Wamura Sako & 585 & 51 \\
3 & Loqloqa Abba & 310 & 27 \\
4 & Werka Werabu & 452 & 39 \\
5 & Yubdo Legabatu & 460 & 40 \\
\hline & Total & 2425 & 210 \\
\hline
\end{tabular}

Source: Dendi District Agriculture Office, 2017 and own computation result

\subsection{Methods of Data Analysis}

\subsubsection{Descriptive statistical analysis}

Descriptive statistical analysis method such as mean, proportions, percentages, and standard deviations were used in the process of examining and describing farm households' demographic characteristics, resource ownership, institutional and infrastructural service, production characteristics and farm input use. Household commercialization index (HCI) defined as the ratio of gross value of tef sold to the gross value of tef produced was used for indicating household level of commercialization. Mathematically, the HCI formula adopted from von Braun et al., (1994) is expressed as:

$$
\mathrm{HCI}_{\mathrm{i}}=\frac{\text { Gross value of } t e f \text { sold }}{\text { Gross value of } \text { tef produced }} \times 100 \%
$$

Where: $\mathrm{HCI}_{\mathrm{i}}=$ Commercialization index of $\mathrm{i}^{\text {th }}$ household in tef sales expressed as a percentage. HCI has a value between zero and one hundred, inclusive. A value closer to zero would indicate a subsistence-oriented household and a value closer to one hundred imply highly commercialized household (Govereh et al., 1999; Berhanu and Moti, 2010; Osmani et al., 2014).

\subsubsection{Econometric analysis}

A Tobit model was used to identify determinants of commercialization of tef producers and the Tobit model was a statistical model proposed by James Tobin to describe the relationship between non-negative dependent variable and independent variable (Tobin, 1958). The dependent variable used in identifying determinants of commercialization of tef producing famers was commercialization index. The commercialization index is censored because some of its values cluster at the limit (i.e. 0 for subsistence tef producers and 100 for fully commercialized farmers). The censored regression model is an option for handling this limited dependent variable.

Since the value of the dependent variable, commercialization index ranges between 0 and 100 (i.e. values are bounded between 0 and 100), the Tobit model was used to identify its determinants. The general formula defining Tobit model is specified as follows:

$y_{i}^{*}=\beta^{\prime} x_{i}+\varepsilon_{i}$

Where: $\mathrm{y}_{\mathrm{i}}^{*}=$ is a latent variable, which is unobserved for values less than 0 and greater than 100 that representing subsistence or fully commercial index;

$\mathrm{x}_{\mathrm{i}}=$ is vector of independent variables, which includes factors affecting level of commercialization;

$\beta=$ is vector of unknown parameters to be estimated; 
$\varepsilon_{\mathrm{i}}=$ is a disturbance term assumed to be normally distributed with zero mean and constant variance $\sigma^{2}$; and $\mathrm{i}=1,2,3$, $\mathrm{n}(\mathrm{n}=$ the number of observation)

Given the observed dependent variable commercialization index $\left(\mathrm{y}_{\mathrm{i}}\right)$, Tobit model is specified as:

$\mathrm{y}_{\mathrm{i}}=\left\{\begin{array}{c}0 \text { if } \mathrm{y}_{\mathrm{i}}^{*} \leq 0 \\ \mathrm{y}^{*} \text { if } 0<\mathrm{y}^{*}<1\end{array}\right.$

The Tobit model is estimated using maximum likelihood estimations. The log likelihood (LL) of the model is:

$$
\ln L=\ln \left(\coprod_{y i>0} f(y i) \coprod_{y i=o} F(0)\right)=\sum_{y i>0} \ln f(y i)+\sum_{y i=0} \ln F(0)
$$

Since $y^{*}$ is assumed to be normally distributed as error terms are assumed to be normally distributed, $\mathrm{f}($.), $\mathrm{F}($.$) and$ hence the log likelihood functions can be written in the form of density function and cumulative density function of the standard normal distribution as: $\emptyset($.$) and \Phi($.$) and the \log$ likelihood function is rewritten as:

$$
\ln L=\sum_{y i>0}\left(-\ln \sigma+\ln \phi\left(\frac{y i-x i \beta}{\sigma}\right)\right)+\sum_{y i=0} \ln \left(1-\Phi\left(\frac{x i \beta}{\sigma}\right)\right)
$$

However, the Tobit coefficients can't be interpreted directly as estimates of the magnitude of marginal effects of changes in the explanatory variables on the expected value of the dependent variable, because there are three main conditional expectations of interest in the Tobit model. These are: the conditional expectation of the underlying latent variable $\left(\mathrm{y}^{*}\right)$; the conditional expectation of the observed dependent variable $(y)$; and the conditional expectations of the uncensored observed dependent variable $(y \mid y>0)$. Following (McDonald and Moffitt, 1980; Greene, 1997; Johnston and Dinardo, 1997) the marginal effects of these conditional expectations, respectively are given as:

$$
\begin{aligned}
& \frac{\partial \mathrm{E}(y * / x)}{\partial x}=\beta \\
& \frac{\partial \mathrm{E}(y / x)}{\partial x}=\beta \Phi\left(\frac{x \beta}{\sigma}\right) \\
& \frac{\partial \operatorname{Pr}(y>0 / x)}{\partial x}=\phi\left(\frac{x \beta}{\sigma}\right) \frac{\beta}{\sigma}
\end{aligned}
$$

The interpretations of these marginal effects depend on the point of interest based on the focus of the study (Greene, 2003). If the interest is to make statements about the conditional mean function in the population despite the censoring, equation 7 is used. If a researcher is interested on average value of the population of study, and how those values vary with covariates, equation 6 is used. If the interest is to interpret about the determinants of average values of the dependent variable among those who have already participated, equation 9 is used. In this study, the three marginal effect results were computed to identify the significant effects of the independent variables on the probability and extent of tef producers' commercialization.

\subsection{Hypothesis and Definition of Variables}

In order to identify factors determining commercialization of tef producers, the following dependent and independent variables were defined and hypothesized.

\section{Dependent variables}

Commercialization index (COMINDX): It is a limited dependent variable, which is measured as the ratio of the gross value of tef sales to gross value of tef produced by the household in 2016/17 production year, expressed in percentage. Definition and hypothesis of independent variables are indicated on Table 2. 
Table 2. Definition and hypothesis of independent variables

\begin{tabular}{|c|c|c|c|c|}
\hline Variables & Notation & Type & Measurement & $\begin{array}{c}\text { Expected } \\
\text { effect }\end{array}$ \\
\hline Sex of the household head & SEXHH & Dummy & $\begin{array}{l}0 \text { if the hh is male; } 1 \\
\text { otherwise (being female) }\end{array}$ & 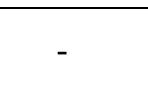 \\
\hline Education level of hh & EDUHH & Continuous & Grades completed & + \\
\hline Household size & HHSIZE & Continuous & $\begin{array}{l}\text { Number of household } \\
\text { members }\end{array}$ & - \\
\hline Farming experience & FREXP & Continuous & No of years & + \\
\hline Livestock owned & LIVOWN & Continuous & TLU & + \\
\hline Number of equines owned & NEQUIO & Continuous & TLU & + \\
\hline Size of land allocated to tef & AREATEF & Continuous & Hectare & + \\
\hline Distance from the nearest market & MRKTDIS & Continuous & Minutes of walk & - \\
\hline Access to credit service & ACREDIT & Dummy & $\begin{array}{l}1 \text { if the hh has access to } \\
\text { credit; } 0 \text { otherwise }\end{array}$ & + \\
\hline Frequency of extension contact & FRQEXT & Discrete & Frequency & + \\
\hline Non/off-farm income & NONFARIN & Continuous & ET Birr & - \\
\hline Lagged market prices of tef & LMKTPRT & Continuous & ET Birr per quintal & + \\
\hline Cooperative membership & COOPMEM & Dummy & $\begin{array}{l}1 \text { if the hh is member of } \\
\text { coop.; } 0 \text { otherwise }\end{array}$ & + \\
\hline
\end{tabular}

\section{RESULT AND DISCUSSION}

\subsection{Demographic and Socio-economic Characteristics of Sample Households}

Table 3 and Table 4 revealed the results of descriptive statistics for the entire variables used in the study. As indicated in Table 3, out of total sample respondents, $172(81.9 \%)$ were male-headed and 38(18.1\%) were femaleheaded households. Regarding cooperative membership, 104(49.52\%) of the sample households were members of cooperatives and 106(50.48\%) were not organized under cooperatives whereas $57(27.14 \%)$ of the sample households has access to credit and $153(72.85 \%)$ doesn't have credit access.

Table 3. General characteristics of sample tef producers (dummy variables)

\begin{tabular}{lcc}
\hline Variables & Frequency & Percent \\
\hline Sex of household head & 38 & \\
Female & 172 & 18.1 \\
Male & & 81.9 \\
Cooperative membership & 104 & \\
Yes & 106 & 49.52 \\
No & & 50.48 \\
Access to credit & 57 & \\
Yes & 153 & 27.14 \\
No & & 72.85 \\
\hline
\end{tabular}

Source: Own survey result, 2017

Accordingly, with regards to the educational level of sample household heads, the average number of formal schooling completed was 4.17 years with a standard deviation of 3.61. The average household size of sample respondents in adult equivalent was 4.40 with standard deviation of 1.58 (Table 4). The average farming experience of sample respondents that an individual continuously engaged in tef production was 18.35 years with standard deviation of 7.33 (Table 4). 
Table 4. General characteristics of sample tef producers (continuous variables)

\begin{tabular}{|c|c|c|c|c|}
\hline Variable & Mean & Std. Dev. & Min & Max \\
\hline Education level (years of formal schooling) & 4.17 & 3.61 & 0 & 15 \\
\hline Household size (Adult equivalent) & 4.40 & 1.58 & 1 & 8.15 \\
\hline Farming experience (No of years) & 18.35 & 7.33 & 4 & 37 \\
\hline Livestock owned (TLU) & 4.18 & 2.30 & 0 & 9.85 \\
\hline Number of equines owned (TLU) & 1.20 & 0.94 & 0 & 3 \\
\hline Size of land under tef production (Hectare) & 1.15 & 0.59 & 0.2 & 2.5 \\
\hline Distance to the nearest market (Minutes) & 67.02 & 26.88 & 30 & 150 \\
\hline Frequency of extension contact (Count) & 7.559 & 5.772 & 0 & 18 \\
\hline Non/off-farm income (ET Birr) ${ }^{\mathrm{a}}$ & 3.899 & 5.106 & 0 & 16 \\
\hline Lagged market prices of tef (ET Birr/qt $)^{a}$ & 1.645 & 0.230 & 1.2 & 2.2 \\
\hline
\end{tabular}

Source: Own survey result, 2017

Note: 'a' indicates the amount of non/off-farm income obtained and lagged market prices of tef in thousands $(000)$ of ETB.

\subsubsection{Resource ownership of sample households}

Ownership of physical resources is an important factor that determines commercialization of smallholder farmers. Land, labor, capital and other resources are the major resources that farmers used to enhance commercialization of tef that provide a greater return. The analysis of survey data depicts that the average total land size owned by the sample households was 1.84 hectare with standard deviation of 1.30 . Out of the total sample households $48(22.8 \%)$ owned less than a hectare of land whereas $34(16.2 \%)$, and $128(61 \%)$ owned one hectare and above one hectare respectively. The average area of land under tef production by sample households was 1.15 hectare with standard deviation of 0.59 (Table 4). The minimum and maximum land allocated for tef production was 0.2 and 2.5 hectares, respectively.

\section{Livestock ownership}

In the district, mixed crop and livestock farming system is dominantly used by farm households. Livestock resources are useful in the livelihoods of smallholders, oxen are the major contributors to crop production by serving as a draft power. Farmers in the study area used oxen to undertake different agronomic practices, out of which ploughing and threshing are the major ones. The mean livestock owned by sample households excluding equines was $4.18 \mathrm{TLU}$ with a standard deviation of 2.3 (Table 4).

\section{Equine ownership}

In the study areas equines are used as a means of transport by smallholder farmers. Equines provide transport services for farm inputs from market to home, harvested farm produce from field to threshing center and for marketing of output. Out of total sample households $57(27.14 \%)$ of them do not own equines. The rest $73(34.76 \%), 62(29.52 \%)$, and 18(8.57\%) of sample households owned one, two and three equines, respectively. The mean equines owned by sample households was 1.2 TLU with a standard deviation of 0.94 (Table 4).

\section{Off/Non-farm income activities}

The major off/non-farm income generating activities in which sample households were participating in the study areas includes: animal cart, daily laborer, remittance and petty trade. From the total of sample households $118(56.19 \%)$ were participating on off/non-farm income generating activities and 92(43.81\%) were not participating on off/non-farm income activities. The mean cash income obtained from off/non-farm income was 3899 ET Birr with standard deviation of 5106 (Table 4).

\subsubsection{Institutional and infrastructural services of farm households}

Having institutional services services are important factors that encourage the commercialization of smallholder farmers through a positive impact on technology transfer.

Frequency of extension contact

The agricultural extension service providers in the district are office of agriculture experts, development agents and researchers. The average frequency of extension service provided for sampled households was 7.56 day/year with standard deviation of 5.77 (Table 4). The minimum and maximum frequency of extension provided for farmers was 0 and 18 days, respectively.

\section{Distance from the nearest market}

The distance from home to the nearest market place where farmers sold their tef produce was an average of 67.02 minutes of walk with standard deviations of 26.88 (Table 4). The minimum and maximum distance that tef producing households travel to the nearest market were 30 and 150 minutes, respectively.

\subsubsection{Crop production characteristics of sample households}

Allocation of land resources and other farm inputs for crop production is a common practice by smallholder 
farmers. As seen from Table 5, out of total land they have sample households in the study areas allocated $88.94 \%$ of land for crop production, $8.42 \%$ for livestock grazing, and $2.65 \%$ for eucalyptus and homestead. This is an indicator that the agro-ecology of the district is conducive for crop production. The mean area of land allocated for crop production by sample households was 2.31 hectares with standard deviation of 1.44.

Table 4. Allocation of land resources by sample households

\begin{tabular}{lllll}
\hline Land allocated & Total areas (hectare) & Proportion (\%) & Mean & Std. Dev. \\
\hline Crop production & 485.63 & 88.94 & 2.31 & 1.44 \\
Grazing for livestock & 45.95 & 8.42 & 0.22 & 0.32 \\
Eucalyptus and homestead & 14.45 & 2.65 & 0.068 & 0.15 \\
\hline Total & 546.03 & 100 & & \\
\hline
\end{tabular}

Source: Own survey result, 2017

The major cereal crops grown in the district include tef, wheat, and maize. The major pulse crops grown are Chickpea and Grass pea. Potato was grown from vegetable crops. In the study area crop rotation (rotation of cereal with pulse crops) is common agronomic practices used by smallholder farmers to increase productivity and to maintain soil fertility status. Accordingly, from the total sample respondents all $100 \%$ of them produced tef, $59.05 \%$ of them produced maize, $37.62 \%$ of them produced wheat, $67.14 \%$ of them produced chick-pea, $53.81 \%$ of them produced Grass pea. As shown in Table 6, tef stands first in terms of cultivated area coverage (54.84\%) and chickpea occupies the second (15.48\%).

Table 5. Area coverage of major crops of sampled households

\begin{tabular}{|c|c|c|c|c|}
\hline Crops cultivated & $\begin{array}{c}\text { Areas cultivated in } 2016 / 17 \\
\text { (ha) }\end{array}$ & $\begin{array}{c}\text { Area proportion } \\
(\%)\end{array}$ & Mean & $\begin{array}{l}\text { Std. } \\
\text { Dev. }\end{array}$ \\
\hline Tef & 266.3 & 54.84 & 1.15 & 0.59 \\
\hline Wheat & 38.88 & 8.01 & 0.19 & 0.33 \\
\hline Maize & 32.16 & 6.62 & 0.15 & 0.19 \\
\hline Chickpea & 75.18 & 15.48 & 0.36 & 0.39 \\
\hline Grass pea & 50.31 & 10.36 & 0.24 & 0.33 \\
\hline $\begin{array}{l}\text { Others (Lentil, Potato, Nug and } \\
\text { Sorghum) }\end{array}$ & 22.79 & 4.69 & 0.11 & 0.25 \\
\hline Total & 485.63 & 100 & & \\
\hline
\end{tabular}

\subsection{Farm Inputs Used in Tef Production by Sample Households in 2016/17}

The common farm inputs used in tef production includes: fertilizers, improved seed, and herbicide. Commercialization level of smallholder farmers' can also be analyzed from input side, from the ratio of purchased inputs to the total inputs used. Thus, describing of farm inputs used by sample households in tef production are important point because commercialization of the output side is often realized with the precondition on commercialization in the input side (Berhanu and Moti, 2010). Adoption of improved high-yielding varieties (HYVs) and chemical fertilizer have a positive effect on smallholders marketed surplus (Tigist, 2015).

The use of improved agricultural inputs increases output side commercialization and improve smallholders' livelihood. Farmers in the study area used different types of inputs for tef in 2016/17 production year. The major agricultural inputs and technologies used by sample households include inorganic fertilizer (NPS and Urea), improved tef seed, herbicide and row planter. The survey result indicates that even if it's not at full recommendation rate out of total sample households $100 \%$ of them use NPS fertilizer and herbicide; $85.2 \% ; 92.8 \%$ and $54.7 \%$ of them used Urea fertilizer, improved seed, and row planter in tef production, respectively.

Additionally, farmers in the study area used leased-in and shared-in land; hired and daily laborer for tef production in 2016/17 production year. As seen from Table 7, by individual households the mean improved seed used per hectare was $23.38 \mathrm{~kg}$ with standard deviation of 6.92; the mean NPS fertilizer used per hectare was 117.63 $\mathrm{kg}$ with standard deviation of 33.92; the mean Urea fertilizer used per hectare was $52.17 \mathrm{~kg}$ with standard deviation of 23.97; the mean herbicide used per hectare was 0.64 litter with standard deviation of 0.28 .

Table 6. Farm input use of sample households for tef in 2016/17 production year

\begin{tabular}{lll}
\hline Inputs used & Mean & Std. Dev. \\
\hline Improved seed $(\mathrm{kg})$ & 23.38 & 6.93 \\
NPS fertilizer $(\mathrm{kg})$ & 117.63 & 33.92 \\
Urea fertilizer (kg) & 52.17 & 23.97 \\
Herbicide 2-4-D (litter) & 0.64 & 0.28 \\
\hline
\end{tabular}

Source: Survey results, 2017 
The transition towards commercial agriculture requires improved inputs and better agronomic practices. Out of improved seed used by sample households Quncho tef variety is a popular one which most of households $121(57.62 \%)$ of them cultivated Quncho variety in 2016/2017 production year and Enatit (DZ-01-354) 66(31.43) is second one. This was indicated by Kebebew et al. (2011) as the good performance of Quncho brought together the coordinated efforts of researchers, extension personnel, district administrators and others involved in the process of seed multiplication and distribution, and technology promotion.

\subsection{Level of Commercialization of Tef Producers}

Following the classification commercialization by Samuel and Sharp (2008) and Tadele et al. (2017) smallholders level of commercialization is grouped into three categories: Less commercialized farmers (those who sold up to $25 \%$ of output), semi-commercialized farmers (those who sold between $25 \%$ and $50 \%$ of output they produce) and commercialized farmers (those farm households who sold more than $50 \%$ of what they have produced). The results from the survey revealed that $26(12.38 \%$ ) of sample households' commercialization index is zero indicating that they are fully subsistent in terms of tef output, 7(3.33\%) are less-commercialized, most of the sample households 92(43.81\%) fall in semi-commercialized category and 85(40.48\%) are commercialized farmers with the high commercialized sample households who sold $75 \%$ of the gross value of its tef output (Table 8).

Table 7. Level of commercialization of tef producers in 2016/17 production year

\begin{tabular}{lll}
\hline Extent of commercialization & Frequency & Percent \\
\hline Subsistent/ Non-commercial $(0 \%)$ & 26 & 12.38 \\
Less-commercialized farmers $(1-25 \%)$ & 7 & 3.33 \\
Semi-commercialized farmers $(25-50 \%)$ & 92 & 43.81 \\
Commercialized farmers $(>=50 \%)$ & 85 & 40.48 \\
\hline Total & 210 & 100 \\
\hline
\end{tabular}

Source: Survey results, 2017

The overall average level of commercialization of tef producers in the district is $46 \%$ in terms of the gross value of tef sold. The average value of tef commercialization indicates that the level of commercialization of tef producers in the study areas was in semi-commercial level. This degree of commercialization in the district is considerably lower than regional average which is about $52 \%$ as reported by ATA (2016). The survey revealed that the supply of tef in the study area shows seasonal variation which is high at harvest and low in August. Figure 2 below shows the kernel density estimates of commercialization index.

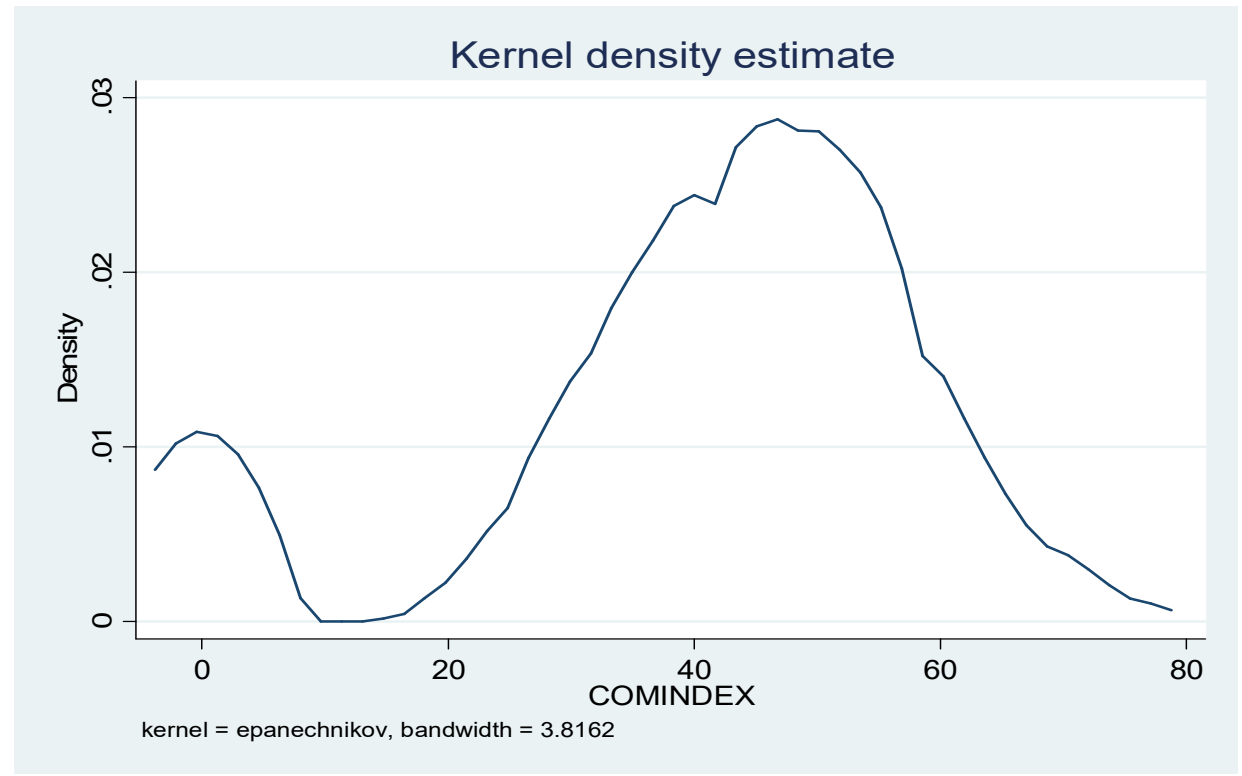

Figure 2. Kernel density estimate of commercialization index

\subsection{Econometric Results}

Prior to the econometric analysis essential tests that verify the model to employ for the analysis were under taken on hypothesized variables. Heckman two-step is an econometric model developed to correct for sample-selection bias (Heckman, 1979). In this study, the result from the Heckman two-step indicated that there is no sample selection bias, because the inverse mills ratio (IMR) which (mills lambda 0.85) was statistically insignificant. This suggested that there is no sample selection bias. Hence, no need to use the Heckman two-step model (Appendix Table 3). As to the survey result of this study, out of total 210 sample households $26(12.38 \%)$ of them didn't sell 
tef even if they produce in $2016 / 17$ production year and the data are censored. Since the commercialization index which is the dependent variable of this study is censored, the maximum likelihood estimation Tobit regression model was used and the analysis of the survey data was carried out by using STATA version 13.

\subsubsection{Determinants of commercialization of tef producers}

The factors determine commercialization level of tef producers was analyzed by Tobit regression model. Before running and fitting the Tobit regression model necessary tests that verify the hypothesized independent variables and existence of econometric problems were performed using appropriate test statistics. For all variables outliers were checked using the box plot graph, so that there were no problems of outliers and no data get lost due to outliers.

The Tobit regression model estimated results in Table 9, showed that the likelihood function of commercialization index was highly significant at $1 \%$ level $\left(\mathrm{LR} \mathrm{chi}^{2}=247.09\right.$ with Prob $\left.>\mathrm{chi}^{2}=0.000\right)$ indicating a strong explanatory power of independent variables to explain factors determining commercialization level of tef producers (goodness of fit of the model). The model result indicated that, out of explanatory variables used in the model, sex of household head, educational level of household head, household size, livestock owned (TLU), land under tef production, frequency of extension contact and non/off-farm income were found to significantly influence the commercialization of tef producers in the study areas (Table 9).

Sex of the household head: Sex of the household head being female was found to negatively influence the level tef commercialization at $10 \%$ significance level. The marginal effects showed that being female headed household decrease the probability of being commercialized by $0.079 \%$ while it decreases the level of tef commercialization by $2.821 \%$, as compared to male headed households. This result was due to the fact that activities accomplished at home like cooking, washing and child care fall upon the females. This specifies that empowering of female household head by proving a continuous and practical training on tef production and marketing is crucial to improve tef commercialization. This result is in line with the findings of Leykun and Jemma (2014) and Tekalign (2014) which found that male-headed households have a better access to information who would provide them with better ability to manage their farms and produce more output for market as compared to female headed households.

Education level of the household head: As it was hypothesized educational level of the household head was found to have positive and significant effect on the level of tef commercialization at $10 \%$ significance level. The marginal effect indicated that as the level of formal education of the household head increased by one grade, increase the probability of being commercialized by $0.009 \%$ whereas it increases the level of tef commercialization by $0.34 \%$. This indicates that attending formal education improves the productivity and amount of tef marketed by adopting improved agricultural technologies. Thus, improving access to formal education of tef producing farmers is required particularly in the study areas and its indispensable for smallholder farmers in general. This result is in line with the findings of Tadele et al. (2017) that found as the level of formal education of the household head increased the level of wheat commercialization.

Household size: Household size measured as adult equivalent was found to have negative and significant influence on tef commercialization at $1 \%$ significance level. The marginal effect shows that as the member of household increased by one adult equivalent decrease the probability of being commercialized by 0.034 while it decreases the level of tef commercialization by $1.213 \%$. This result is expected because households with more household member tend to consume more of tef output produced and less is available for sales. This result is similar with findings of Efa et al. (2016) and Girma (2015) who showed that the larger household size consumes more output of tef produced, have the lower marketed surplus and less is available for sales.

Size of land under tef production: Size of land under tef production was positively and significantly affect the level tef commercialization at $1 \%$ significance level. The marginal effect shows that allocating one additional hectare of land to tef production would increase the probability of being commercialized by $0.129 \%$ whereas it increases the level of tef commercialization by $4.643 \%$. This result implies that those households allocating one more additional hectare of land from self-owned, by rented-in or shared-in land raises the level of commercialization. This result is consistent with the findings of Efa et al. (2016) and Leykun and Jemma (2014) who reported that land size cultivated has a positive significant outcome on being transition and commercial farmer and the larger area allocated to production increases the quantity of produce available for sale. 
Table 8. Determinants of sample households' commercialization of tef

\begin{tabular}{|c|c|c|c|c|}
\hline \multirow{3}{*}{ Independent Variables } & \multirow{3}{*}{ Coefficient } & \multirow{3}{*}{$\begin{array}{c}\text { Robust Std. } \\
\text { Err. }\end{array}$} & \multicolumn{2}{|c|}{ Marginal Effects } \\
\hline & & & $\partial\left(y^{*} / x\right)$ & $\partial \mathrm{P}(y>0 / x) \quad(x \beta) \beta$ \\
\hline & & & $\partial x$ & $(\sigma)_{\sigma}$ \\
\hline Sex of household head & $-4.175^{*}$ & 2.153 & -0.079 & -2.821 \\
\hline Education level of household head & $0.504 *$ & 0.299 & 0.009 & 0.340 \\
\hline Household size (Adult Equivalent) $^{\mathrm{a}}$ & $-1.795 * * *$ & 0.553 & -0.034 & -1.213 \\
\hline Farming experience of household & 0.178 & 0.130 & 0.003 & 0.121 \\
\hline Livestock owned (TLU) ${ }^{\mathrm{b}}$ & $1.197 * *$ & 0.497 & 0.023 & 0.809 \\
\hline Equines owned (TLU) & 1.973 & 1.202 & 0.037 & 1.333 \\
\hline Land area under tef production (ha) & $6.872 * * *$ & 1.945 & 0.129 & 4.643 \\
\hline Distance from the nearest market & -2.450 & 2.064 & -0.046 & -1.655 \\
\hline Access to credit service & 0.714 & 2.323 & 0.013 & 0.482 \\
\hline Frequency of extension contact & $1.309 * * *$ & 0.210 & 0.025 & 0.884 \\
\hline Non/off-farm income (ETB)c & $-0.342 * *$ & 0.170 & -0.006 & -0.231 \\
\hline Lagged market prices $(\mathrm{ETB})^{\mathrm{c}}$ & 0.018 & 3.401 & 0.0003 & 0.012 \\
\hline Cooperative membership & -2.540 & 2.169 & -0.048 & -1.716 \\
\hline Constant & $22.972 * * *$ & 6.924 & & \\
\hline /Sigma & 10.863 & 0.590 & & \\
\hline \multirow{4}{*}{$\begin{array}{l}\text { Number of observation }=210 \\
\text { Left-censored observation }=26 \\
\text { Uncensored observation }=184\end{array}$} & & & \multicolumn{2}{|c|}{ Log pseudolikelihood $=-731$} \\
\hline & & & \multicolumn{2}{|c|}{$\operatorname{LR~chi}^{2}(13)=247.09$} \\
\hline & & & \multicolumn{2}{|c|}{ Prob $>$ chi $^{2}=0.000$} \\
\hline & & & Pseudo $\mathrm{R}^{2}=$ & 0.144 \\
\hline \multicolumn{5}{|c|}{$\operatorname{Pr}(\mathrm{COMINDEX}>0)=0.999$} \\
\hline & OMIND $\mid \mathrm{CON}$ & IIND $>0)=39$ & & \\
\hline
\end{tabular}

Source: Own computation result, 2017

Note: Symbols $* * *, * *$ and $*$ indicates significant at $1 \%, 5 \%$ and $10 \%$ levels, respectively.

' $a$ ' indicates adult equivalent conversion factor of household size shown in Appendix Table 1.

' $b$ ' indicates conversion factor of Tropical Livestock Unit presented in Appendix Table 2.

'c' indicates the amount of non/off-farm income obtained in thousands (000) ETB.

Livestock owned: Number of livestock owned measured in TLU was found to positively and significantly contribute to the level of tef commercialization at 5\% significance level. The marginal effect indicates that excluding equines, increasing the number of livestock by one TLU increase the probability of being commercialized by $0.023 \%$ whereas it increases the level of tef commercialization by $0.809 \%$. This is due to the positive impact of livestock on the crop production enterprises by providing cash to purchase improved seed and in-organic fertilizer for tef production, and oxen serve as a traction power. This result is in line with Mebrahatom (2014) and Tadele et al. (2017) found that the positive effect of livestock ownership on the level of commercialization due to significant effect on production.

Frequency of extension contact: The result shows that frequency of extension contacts significantly and positively related with tef commercialization at $1 \%$ significant level. The marginal effect shows that an increase in frequency of extension contact by one day would increase the probability of being commercialized by $0.025 \%$ whereas it increases the level of tef commercialization by $0.884 \%$. This result implies that the technical advice provided for farmers by development agent, experts of agriculture and researchers on tef production (on improved seed, fertilizer application, row planting) and tef marketing enhance the level of tef commercialization and this indicates the importance of professional advice on being commercial farmer. This result is consistent with the findings of Tekalign (2014) and Girma (2015) who found that extension contact and advice significantly and positively influence crop commercialization and marketed surplus of tef, respectively.

Non/off-farm income: As expected income obtained from non/off-farm activities influenced the level of commercialization negatively and statistically at 5\% significant level. The marginal effect shows that an increase in the amount off/non-farm income by one thousand ET birr decrease the probability of being commercialized by $0.006 \%$ while it decreases the level of tef commercialization by $0.231 \%$. This result is due to the reason that households obtained income from non/off-farm activities were not encouraged to cultivate tef on more area of land and they used the amount produced for home consumption. This result is supported by the findings of 
Tekalign (2014) who found that participation in non/off-farm activities negatively impacts the degree of crop commercialization.

\section{CONCLUSION AND RECOMMENDATIONS}

The study was aimed at analyzing the level of commercialization of tef and on identifying the factors affecting commercialization of tef producers in Dendi district of Oromia region, Central Ethiopia. Commercial transformation of smallholder farmers is vital to improve the well-being of farm households. Results of the descriptive statistics revealed that $26(12.38 \%)$ of sample households are subsistent producer, $7(3.33 \%)$ are lesscommercial, $92(43.81 \%)$ are semi-commercial and $85(40.48 \%)$ are commercial farmers in tef production in $2016 / 17$ production year. The average level of commercialization of tef producers in the study area is $46 \%$. The result of Tobit regression model shows that educational level of household head, livestock owned (TLU), size of land under tef production and frequency of extension contact were found to positively and significantly contribute to the commercialization of tef, whereas sex of household head, household size (adult equivalent) and non/offfarm income were found to negatively and significantly affect it.

From the findings of this study the following relevant recommendations are drawn, in order to help to design appropriate intervention strategies to improve the smallholder farmers commercialization level. The result of the study showed that being female household head negatively affect the level tef commercialization as compared to male household head. This is due to the fact that different activities accomplished at home for the wellbeing of the household consumes more time and hinder female household heads to attend their farm land for improved tef production that is required to increase the proportion of tef sold. Hence, support given to female household head and empowering of female household head through training and supply of improved technology that encourage them to patriciate in tef marketing is indispensable.

Education level of the household head was found to have positive and significant effect on the level of tef commercialization. Thus, improving access to education should be focused to enhance commercialization of tef producers and government should give emphasis on encouraging farmers to learn adult and formal education and providing intermediate practical based training on market-oriented production. An increase in household size was found to have negative and significant influence on tef commercialization. This is because households with large household member consume more proportion of tef produce and reduce the amount that is going to be sold. Since production resources are limited intervention on family planning based on interest of farmers by showing its negative impact is important in the study areas. In addition, provision of rural employment opportunities is essential to reduce high dependence on farm output and to increase the proportion outputs sold.

Livestock owned in TLU contribute to the level of tef commercialization positively. Thus, efforts are required in improving number of livestock ownership is essential for smallholder farmers as source of cash to purchase improved seed and inorganic fertilizers and provide a traction power to enhance commercialization of tef producers. Size of land allocated to tef production positively and significantly affected the level tef commercialization. However, increasing the size of landholding was impossible since land is a limited resource. Interventions are needed to increase productivity of tef per unit area of land through delivering appropriate and improved tef production technology that increase smallholder farmers commercialization. Hence, proper utilization of land resource requires intensifying the farm practices through provision of sustainable and timely supply of inputs, increasing the farmers' awareness on agronomic practices like row planting and proper application of inputs helps the farmer to produce and supply more tef to the market.

Extension contact is a significant contributor to the commercialization of tef producers. Provision of technical advice to the farmers on tef production and marketing enhance the level of tef commercialization. Therefore, joint effort of development agent, agricultural experts, researchers and other stakeholders on identifying and solving problems, availing of new agricultural technology, transfer of improved technology and information to farmers are compulsory to enhance commercialization. Income earned from non/off-farm activities negatively influenced commercialization tef producers. This was due to the fact that households obtained income from non/off-farm activities were not encouraged to cultivate more area of land and consume tef produced at home. Therefore, interventions intended at raising the efficiency of farmers to reduce farmers involvement in non/off-farm activities and changing the attitudes of farmers to use cash income obtained from non/off-farm activities to strengthen their agricultural production and market orientation is crucial.

\section{REFERENCES}

ADEA (Association for the Development of Education for Africa). 2014. Ethiopia Country Report for the 2014 Ministerial Conference on Youth Employment, 21-23 July 2014. Abidjan, Coted'ivoire.

ATA (Agricultural Transformation Agency). 2016. Agricultural Commercialization Clusters (ACC). retrieved form: http://www.ata.gov.et/programs/agricultural-commercialization-clusters-acc/oromia-region/.

ATA (Agricultural Transformation Agency). 2017. Agricultural Transformation Agenda. Annual Report of 201617. Addis Ababa, Ethiopia 
Barrett, C.B. 2008. Smallholder market participation: Concepts and evidence from Eastern and Southern Africa. Food Policy, 33(2008): 299-317.

Berhanu Gebremedhin and Moti Jaleta. 2010. Commercialization of smallholders: Does market orientation translate into market participation? Improving productivity and market success of Ethiopian farmers project (IPMS) - (ILRI). Working Paper No. 22. Addis Abeba, Ethiopia.

CSA (Central Statistical Agency). 2016. Agricultural Sample Survey 2015/2016 (2008 E.C): Report on area and production of major crops, volume-I. Addis Ababa, Ethiopia.

DDAO (Dendi District Agriculture Office). 2017. Annual report of Dendi district, Oromia region, Ethiopia.

Efa Gobena, Degye Goshu, Tinsae Demisie and Tadesse Kenea. 2016. Determinants of market participation and intensity of marketed surplus of tef producers in Bacho and Dawo districts of Oromia, Ethiopia. Journal of Agricultural Economics and Development, 5(2): 20-32.

Gebreslassie Atsbaha and Bekele Tessema. 2012. A Review of Ethiopian Agriculture: Roles, policy and smallscale farming systems. Country analysis: Ethiopia and D.R. Congo, 37.

Girma Alemu. 2015. Market Performance and Determinants of Marketed Surplus of Tef in Bacho Woreda of South West Shewa Zone, Oromia National Regional State. MSc Thesis, Haramaya University, Haramaya, Ethiopia.

Govereh, J., Jayne, T.S. and Nyoro, J. 1999. Smallholder commercialization, interlinked markets and food crop productivity: Cross-country evidence in Eastern and Southern Africa. Michigan State University (MSU), United States.

Greene, W.H. 1997. Econometric Analysis. $3^{\text {rd }}$ Edition. Macmillan: New York.

Greene, W.H. 2003. Econometric Analysis. $5^{\text {th }}$ Edition. Prentice-Hall, Upper Saddle River, New Jersey, 07458. New York University.

Heckman, J.J. 1979. Sample Selection Bias as a Specification Error. Econometric Society, 47(1): 153- 161.

Johnston, J., Dinardo, J. 1997. Econometric Methods, $4^{\text {th }}$ Edition. MacGraw-Hill. New York, 16(2000): 139-142.

Kebebew Assefa, Sherif Aliye, Getachew Belay, Gizaw Metaferia, Hailu Tefera and Mark E. Sorrells. 2011. Quncho: the first popular tef variety in Ethiopia. International Journal of Agricultural Sustainability, 9(1): 25-34

Leykun Birhanu and Jema Haji. 2014. Econometrics analysis of factors affecting market participation of smallholders farming in central Ethiopia. Journal of Agricultural Economics and Extension and Rural Development, 2(6): 84-104.

McDonald, J.F. and Moffitt, R.A. 1980. The Uses of Tobit Analysis. The Review of Economics and Statistics, 62(2): 318- 321.

Mebrahatom Medhane. 2014. Determinants of commercialization of tef and its factor productivity outcome: The case of Tahtay Qoraro woreda, Northwest Zone of Tigray, Ethiopia. MSc Thesis, Haramaya University, Haramaya, Ethiopia.

MoARD (Ministry of Agriculture and Rural Development). 2010. Ethiopia's Agricultural and Sector Policy and Investment Framework (PIF): 2010-2020, Addis Ababa, Ethiopia.

MoFED (Ministry of Finance and Economic Development). 2010. Growth and Transformational Plan (GTP 20102015). Addis Ababa. Ethiopia.

MoFED (Ministry of Finance and Economic Development). 2015. Growth and Transformational Plan (GTP 20152020). Addis Ababa. Ethiopia.

Osmani, A.G., Islam, K., Ghosh, B.C. and Hossain, E. 2014. Commercialization of smallholder farmers and its welfare outcomes: Evidence from Durgapur Upazila of Rajshahi district, Bangladesh. Journal of World Economic Research, 3(6): 119-126.

Pauw, S. 2017. Agricultural Commercialization in Ethiopia: A Review of Warehouse Receipts in the Maize, Wheat, Sorghum and Tef Value Chains. USAID/Ethiopia Agriculture Knowledge, Learning, Documentation and Policy Project, Addis Ababa.

Samuel Gebreselassie and Sharp, K. 2008. Commercialization of smallholder agriculture in selected tef-growing areas of Ethiopia. Paper presented at the Fifth International Conference on the Ethiopian Economy, June 2007. Addis Ababa, Ethiopia.

Tadele Mamo, Wudineh Getahun, Agajie Tesfaye, Ali Chebil, Tesfaye Solomon, Aden Aw-Hassan, Tolessa Debele and Solomon Assefa. 2017. Analysis of wheat commercialization in Ethiopia: The case of SARD-SC wheat project innovation platform sites. African Journal of Agricultural Research, 12(10): 841-849.

Tekalign Diyana. 2014. Determinants and Welfare Outcomes of Commercialization of Smallholders' Farming: The case of Anchar Woreda, West Hararghe, Ethiopia. MSc Thesis Haramaya University, Haramaya, Ethiopia.

Tigist Mekonnen. 2015. Agricultural Technology Adoption and Market Participation under Learning Externality: Impact Evaluation on Small-scale Agriculture from Rural Ethiopia. Working Paper No. 2015/06 September, 2015. Maastricht School of Management.

Tobin, J. 1958. Estimation on Relationship for Limited Dependent Variables. Econometrica, 26(1): 24-36. 
Vavilov, N.I. 1951. The Origin, Variation, Immunity and Breeding of Cultivated Plants. Translated from the Russian by K.S. Chester. Ronal Press Co, 13(1/6): New York, USA.

von Braun, J. and Kennedy, E. (eds). 1994. Agricultural commercialization, economic development, and nutrition. The Johns Hopkins University Press, Baltimore and London. pp. 11-33.

Yamane, T. 1967. Statistics: An Introductory Analysis, $2^{\text {nd }}$ Edition. Harper \& Row, Publisher, New York. pp. 919.

\section{APPENDIX}

Appendix Table 1. Conversion factor used to compute household size in adult equivalent

\begin{tabular}{ccc}
\hline Age group (years) & Male & Female \\
\hline$<10$ & 0.6 & 0.6 \\
$10-13$ & 0.9 & 0.8 \\
$14-16$ & 1 & 0.75 \\
$17-50$ & 1 & 0.75 \\
$>50$ & 1 & 0.75 \\
\hline
\end{tabular}

Source: Samuel and Sharp, 2008

Appendix Table 2. Conversion factors used to estimate Tropical Livestock Unit equivalents

\begin{tabular}{ll}
\hline Livestock category & Tropical Livestock Unit (TLU) \\
\hline Camel & 1.25 \\
Horse & 1.10 \\
Ox and Cow & 1.00 \\
Weaned Calf & 0.34 \\
Heifer & 0.75 \\
Calf & 0.25 \\
Donkey (adult) & 0.70 \\
Donkey (young) & 0.35 \\
Sheep and Goat (adult) & 0.13 \\
Sheep and Goat (young) & 0.06 \\
Chicken & 0.013 \\
\hline Source: Stork, et al, 1991
\end{tabular}

Source: Storck, et al., 1991 
Appendix Table 1. Heckman two-step result for sample selection bias Heckman selection model -- two-step estimates (regression model with sample selection)

$\begin{array}{lll}\text { Number of obs } & = & 210 \\ \text { Censored obs } & = & 26 \\ \text { Uncensored obs }= & & 184\end{array}$

Wald chi2(12) $=18498.52$

Prob $>$ chi $2=0.0000$

\begin{tabular}{|c|c|c|c|c|c|c|}
\hline & Coef. & Std. Err. & $\mathrm{z}$ & $\mathrm{P}>\mathrm{Z}$ & [95\% Conf. & Interval] \\
\hline $\begin{array}{l}\text { Mkt Particip. } \\
\text { SEXHH }\end{array}$ & 0.021588 & 0.021868 & 0.99 & 0.324 & -0.02127 & 0.064449 \\
\hline EDUHH & 0.007419 & 0.002601 & 2.85 & 0.004 & 0.002322 & 0.012516 \\
\hline HHSIZE & 0.017042 & 0.004928 & 3.46 & 0.001 & 0.007384 & 0.0267 \\
\hline FRQEXT & $-8.3 \mathrm{E}-05$ & 0.001205 & -0.07 & 0.945 & -0.00245 & 0.00228 \\
\hline LIVESTO & 0.004719 & 0.004691 & 1.01 & 0.314 & -0.00448 & 0.013913 \\
\hline EQUINE & -0.0208 & 0.010815 & -1.92 & 0.054 & -0.04200 & 0.000394 \\
\hline AREATEF & 0.025506 & 0.017394 & 1.47 & 0.143 & -0.00859 & 0.059598 \\
\hline MRKTDIS & 0.001495 & 0.00033 & 4.53 & 0.000 & 0.000848 & 0.002142 \\
\hline ACREDIT & 0.070876 & 0.015994 & 4.43 & 0.000 & 0.039528 & 0.102223 \\
\hline EXTTEFF & 0.096281 & 0.017601 & 5.47 & 0.000 & 0.061784 & 0.130779 \\
\hline LMKTPR & 0.000308 & $2.45 \mathrm{E}-05$ & 12.56 & 0.000 & 0.00026 & 0.000356 \\
\hline COOPME & 0.023021 & 0.020971 & 1.10 & 0.272 & -0.01808 & 0.064123 \\
\hline Quantity Sold & & & & & & \\
\hline SEXHH & -0.00416 & 1.511194 & 0.00 & 0.998 & -2.96605 & 2.957721 \\
\hline EDUHH & 1.208018 & 1.11725 & 1.08 & 0.280 & -0.98175 & 3.397788 \\
\hline HHSIZE & -1.34563 & 0.713111 & -1.89 & 0.059 & -2.7433 & 0.052044 \\
\hline FRQEXT & 0.31099 & 0.219181 & 1.42 & 0.156 & -0.1186 & 0.740576 \\
\hline LIVESTO & 0.810179 & 0.423933 & 1.91 & 0.056 & -0.02071 & 1.641073 \\
\hline EQUINE & 2.862274 & 2.31905 & 1.23 & 0.217 & -1.68298 & 7.407529 \\
\hline AREATEF & 16.00782 & 10.36319 & 1.54 & 0.122 & -4.30367 & 36.3193 \\
\hline MRKTDIS & 0.015807 & 0.016659 & 0.95 & 0.343 & -0.01684 & 0.048457 \\
\hline ACREDIT & 1.057309 & 1.503292 & 0.70 & 0.482 & -1.88909 & 4.003706 \\
\hline EXTTEFF & 0.903822 & 1.257879 & 0.72 & 0.472 & -1.56158 & 3.369219 \\
\hline LMKTPR & 0.004396 & 0.003315 & 1.33 & 0.185 & -0.0021 & 0.010894 \\
\hline Constant & -21.8463 & 14.26831 & -1.53 & 0.126 & -49.8117 & 6.119094 \\
\hline \multicolumn{7}{|l|}{ Mills } \\
\hline lambda & -0.00979 & 0.055059 & -0.18 & 0.859 & -0.1177009 & 0.0981253 \\
\hline rho & -0.09995 & & & & & \\
\hline sigma & 0.09792 & & & & & \\
\hline
\end{tabular}

Source: Own computation from survey result, 2017 